\author{
WITOLD MAŁECKI \\ ORCID: 0000-0002-8819-0317 \\ Uniwersytet Wrocławski \\ witold.malecki@uwr.edu.pl
}

\title{
O właściwej i niewłaściwej reglamentacji podejmowania działalności gospodarczej
}

\begin{abstract}
Abstrakt: Katalog instrumentów reglamentacji podejmowania działalności gospodarczej ujęty w rozdziale 4 Prawa przedsiębiorców (koncesja, zezwolenie, wpis do rejestru działalności regulowanej) nie wyczerpuje ogólnej struktury reglamentacji podejmowania działalności gospodarczej w polskim porządku prawnym. W licznych ustawach regulujących poszczególne dziedziny działalności gospodarczej unormowane są instrumenty prawne warunkujące dopuszczalność podjęcia działalności znajdujące się poza katalogiem wynikającym z przepisów Prawa przedsiębiorców jakkolwiek wywołują one zbliżony skutek do instrumentów wynikających z Prawa przedsiębiorców, ich istota prawna jest odmienna. Instrumenty te należy zaliczyć do kategorii niewłaściwej reglamentacji podejmowania działalności gospodarczej, w odróżnieniu od reglamentacji właściwej, wpisującej się w konstrukcję ujętą w rozdziale 4 Prawa przedsiębiorców. Z uwagi na rozproszenie instrumentów niewłaściwej reglamentacji podejmowania działalności gospodarczej w trzech różnych gałęziach prawa w obrębie reglamentacji niewłaściwej wypada wyróżnić reglamentację prawnogospodarczą, prawnoadministracyjną i prawnopodatkową.
\end{abstract}

Słowa kluczowe: reglamentacja działalności gospodarczej, reglamentacja niewłaściwa, koncesja, zezwolenie, działalność regulowana.

\section{Uwagi wstępne - pojęcie reglamentacji działalności gospodarczej}

Pojęcie reglamentacji działalności gospodarczej, należące do głównych pojęć publicznego prawa gospodarczego, jest ujmowane przez doktrynę w sposób wiel- 
ce niejednolity ${ }^{1}$. W najszerszym ujęciu termin „reglamentacja działalności gospodarczej” bywa odnoszony do ogółu regulacji prawnych normujących działalność gospodarczą, wypełniając tym samym w zasadzie w całości ramy publicznego prawa gospodarczego ${ }^{2}$. W tym ujęciu każda norma prawna, w której zakresie zastosowania znajdują się stany faktyczne związane z działalnością gospodarczą, wpisywałaby się w zakres reglamentacji działalności gospodarczej — jedynym kryterium wyznaczania granic reglamentacji stałby się zatem zakres zastosowania odnoszonych do niej norm. $Z$ tej przyczyny ujmowanie reglamentacji działalności gospodarczej sensu largissimo nie zasługuje na aprobatę — reglamentacja stałaby się bowiem ledwie ornamentem słownym służącym opisowi szerokiej grupy wielorakich norm dotyczących różnych aspektów działalności gospodarczej; byłaby pozbawiona autonomicznej tożsamości i wyraźnych cech znamiennych wyróżniających ją w obrębie zbioru unormowań publicznego prawa gospodarczego.

We współczesnej nauce przeważają dwa inne ujęcia reglamentacji działalności gospodarczej. W pierwszym z nich (sensu stricto) pojęcie reglamentacji wiązane jest wyłącznie ze sferą podejmowania działalności gospodarczej — istotą reglamentacji jest uzależnienie dopuszczalności rozpoczęcia wykonywania określonych rodzajów działalności gospodarczej od zrealizowania przepisanych prawem wymogów materialnych i spełnienia przesłanek formalnych, takich jak otrzymanie od właściwego organu władzy publicznej indywidualnego aktu administracyjnego o charakterze zezwalającym lub uzyskanie wpisu do odpowiedniego rejestru $^{3}$. W drugim ujęciu (sensu largo) o tożsamości reglamentacji działalności gospodarczej decydują dwa podstawowe czynniki — operowanie normami ustanawiającymi wymogi i ograniczenia (nakazy i zakazy) adresowane do podmiotów działalności gospodarczej oraz realizowanie za pomocą norm celu publicznego, wyrażającego się $\mathrm{w}$ preferowaniu interesu zbiorowości w przeciwstawieniu do interesów indywidualnych ${ }^{4}$. W tym ujęciu normy reglamentacyjne regulują sferę

${ }^{1}$ O sposobach pojmowania reglamentacji (w tym reglamentacji działalności gospodarczej) zob. m.in. M. Waligórski, Administracyjna regulacja działalności gospodarczej. Problemy prawnej reglamentacji, Poznań 1998, s. 68-75.

${ }^{2}$ Krytyczne stanowisko co do zasadności posługiwania się pojęciem reglamentacji w jego najszerszym ujęciu wyraża B. Popowska - eadem, Klasyfikacja funkcji administracji w nauce publicznego prawa gospodarczego, [w:] Funkcje współczesnej administracji gospodarczej, red. B. Popowska, Poznań 2006, s. 84.

3 Zob. M. Strzelbicki, Reglamentacja działalności gospodarczej w świetle ustawy Prawo przedsiębiorców na tle unormowań wcześniejszych, „Ruch Prawniczy, Ekonomiczny i Socjologiczny" 2018 , nr 4, s. 75.

4 T. Kocowski, Reglamentacja działalności gospodarczej, [w:] System Prawa Administracyjnego, t. 8a. Publiczne prawo gospodarcze, red. J. Grabowski, L. Kieres, A. Walaszek-Pyzioł, Warszawa 2018, s. 720-721. Ze względu na wskazane okoliczności reglamentację działalności gospodarczej należy uznać za formę interwencjonizmu państwowego oraz wyraz ograniczenia swobody działalności gospodarczej; zob. K. Strzyczkowski, Prawo gospodarcze publiczne, Warszawa 2011, s. 155 . 
nie tylko podejmowania działalności gospodarczej, lecz także jej wykonywania oraz zakończenia 5 .

Określając treść unormowań ustawy z dnia 6 marca 2018 roku Prawo przedsiębiorców ${ }^{6}$, ustawodawca postanowił wprowadzić pojęcie reglamentacji działalności gospodarczej do języka prawnego ${ }^{7}$. Tytuł „Reglamentacja działalności gospodarczej" nosi bowiem rozdział 4 ustawy, w którym zawarto przepisy dotyczące instrumentów ograniczania swobody podejmowania działalności gospodarczej w określonych jej dziedzinach — koncesji, zezwoleń oraz wpisu do rejestru działalności regulowanej. Tym sposobem ustawodawca opowiedział się za pierwszym (sensu stricto) z przedstawionych ujęć reglamentacji działalności gospodarczej. Decyzja ustawodawcy, której znaczenie — wskutek ewentualnych przyszłych zmian legislacyjnych - może okazać się przemijające, nie powinna jednakże wpływać na zasadność dalszego posługiwania się przez doktrynę także drugim (sensu largo) ujęciem reglamentacji działalności gospodarczej, wokół którego ukształtowała się doniosła literatura ${ }^{8}$. Z uwagi na dążenie do podkreślenia tej okoliczności i konieczność precyzyjnego wskazania zakresu analiz w niniejszym artykule, dotyczącym sfery podejmowania działalności gospodarczej, stosowane będzie pojęcie reglamentacji podejmowania działalności gospodarczej.

\section{Reglamentacja podejmowania działalności gospodarczej w wymiarze właściwym i niewłaściwym}

Kierując się kryterium uwarunkowania dopuszczalności podjęcia określonych rodzajów działalności gospodarczej przepisami prawa, należy w ogólności wyróżnić cztery kategorie działalności gospodarczej9:

1. działalność, której podjęcie przez przedsiębiorców prywatnych nie jest dopuszczalne;

5 Należy przy tym zaznaczyć, że ograniczenia reglamentacyjne mogą powstawać zarówno z mocy prawa, jak i wskutek aktów administracyjnych; zob. T. Kocowski, Reglamentacja działalności gospodarczej w polskim administracyjnym prawie gospodarczym, Wrocław 2009, s. 220-325.

6 Dz.U. z 2019 r. poz. 1292 ze zm.

7 Warto wszakże zaznaczyć, że pojęcie reglamentacji pozataryfowej było już uprzednio objęte definicją legalną w art. $53 \S 33$ ustawy z dnia 10 września 1999 roku - Kodeks karny skarbowy (Dz.U. z 2018 r. poz. 1958 ze zm.).

8 Podstawową pozycją jest tu monografia T. Kocowskiego Reglamentacja działalności gospodarczej $w$ polskim administracyjnym prawie gospodarczym.

9 Zob. M. Szydło, Reglamentacja podejmowania działalności gospodarczej w nowej ustawie o swobodzie działalności gospodarczej, „Przegląd Ustawodawstwa Gospodarczego” 2004, nr 12, s. 2-3; idem, Swoboda działalności gospodarczej, Wrocław 2005, s. 204-205. 
2. działalność, której podjęcie wymaga uprzedniego uzyskania indywidualnego aktu administracyjnego (decyzji administracyjnej);

3. działalność, której podjęcie wymaga dokonania notyfikacji właściwemu organowi władzy publicznej;

4. działalność, której podjęcie nie wymaga wypełnienia żadnych szczególnych obowiązków wobec organów władzy publicznej (działalność wolna) ${ }^{10}$.

Zarysowanej w ten sposób ogólnej strukturze reglamentacji podejmowania działalności gospodarczej, w odniesieniu do pkt 2-4, zdaje się odpowiadać treść rozdziału 4 Prawa przedsiębiorców, zatytułowanego „Reglamentacja działalności gospodarczej”. Na podstawie treści zawartego w nim przepisu art. 37 ust. 1 w literaturze często konstruowany jest podział działalności gospodarczej (dostępnej dla przedsiębiorców prywatnych) na działalność koncesjonowaną, działalność objętą wymogiem uzyskania zezwolenia (lub zrównanej z nim licencji1 ${ }^{11}$ ), działalność regulowaną oraz działalność wolną. W tym rozumieniu działalnością wolną byłaby każda działalność, która nie wymaga uzyskania koncesji lub zezwolenia i nie jest działalnością regulowaną.

Podział ten - przy założeniu, że ma charakter podziału zupełnego (to jest obejmującego ogół rodzajów działalności gospodarczej dostępnej dla przedsiębiorców prywatnych) - nie jest jednak trafny. Na gruncie obowiązującego ustawodawstwa nie sposób bowiem przyjąć, że czteroelementowy podział rodzajów działalności gospodarczej, opierający się na instrumentach reglamentacji podejmowania działalności gospodarczej wskazanych w Prawie przedsiębiorców, wyczerpuje (konsumuje) ogólną strukturę reglamentacji podejmowania działalności gospodarczej. W szczególności nie byłoby prawdziwe twierdzenie, że koncesje i zezwolenia (licencje) to jedyne kategorie indywidualnych aktów administracyjnych, których uzyskanie warunkuje dopuszczalność podjęcia określonego rodzaju działalności gospodarczej, a ponadto że rejestry działalności regulowanej

10 Słynna myśl Gajusa, ujęta w Instytucjach, głosi: „A najogólniejszy oto podział co do prawa osób jest ten, że wszyscy ludzie są albo wolni, albo niewolni” („Et quidem summa divisio de iure personarum haec est, quod omnes homines aut liberi sunt, aut servi”), cyt. za: A. Dębiński, Rzymskie prawo prywatne, Warszawa 2008, s. 139. Parafrazując to stwierdzenie, można stwierdzić, że najogólniejszy podział rodzajów działalności gospodarczej (według kryterium prawnej dopuszczalności jej podjęcia) obejmuje działalność wolną i niewolną, to jest działalność, której podjęcie wymaga spełnienia szczególnych warunków.

11 Licencja jako decyzja administracyjna zezwalająca na podjęcie określonych rodzajów działalności gospodarczej występuje obecnie w przepisach ustawy z dnia 6 września 2001 roku o transporcie drogowym (Dz.U. z 2019 r. poz. 2140 ze zm.) oraz ustawy z dnia 28 marca 2003 roku o transporcie kolejowym (Dz.U. z 2019 r. poz. 710 ze zm.). Zgodnie z art. 5a ust. 3 i art. 5b ust. 4 ustawy o transporcie drogowym oraz art. 45 ust. 3 ustawy o transporcie kolejowym licencje regulowane odpowiednimi przepisami obu ustaw są zezwoleniami w rozumieniu Prawa przedsiębiorców. O przyczynach pozostawienia w polskim porządku prawnym instytucji licencji jako decyzji administracyjnej zezwalającej na podjęcie określonych rodzajów działalności gospodarczej zob. K. Kiczka, T. Kocowski, W. Małecki, Licencje jako akty administracyjne w działalności gospodarczej. Zagadnienia wybrane, [w:] Sektory infrastrukturalne. Problematyka prawna, red. M. Królikowska-Olczak, Warszawa 2018, s. 117-122.

Prawo 329, 2020

(C) for this edition by CNS 
to jedyna kategoria rejestrów prowadzonych dla pewnych rodzajów działalności gospodarczej, w których wpis stanowi wyraz prawnej dopuszczalności podjęcia działalności ${ }^{12}$. Analiza ustaw normujących podjęcie i wykonywanie poszczególnych rodzajów działalności gospodarczej wskazuje na występowanie licznych instrumentów prawnych warunkujących dopuszczalność podjęcia działalności poza katalogiem wynikającym z przepisów Prawa przedsiębiorców.

Na podstawie tej obserwacji wypada zaproponować wyróżnienie właściwej i niewłaściwej reglamentacji podejmowania działalności gospodarczej. Reglamentacja w wymiarze właściwym odnosiłaby się do instrumentów stypizowanych w Prawie przedsiębiorców (koncesja, zezwolenie, wpis do rejestru działalności regulowanej), wprost objętych przez ustawodawcę pojęciem reglamentacji działalności gospodarczej (z uwagi na tytuł rozdziału 4 Prawa przedsiębiorców). Reglamentacja $\mathrm{w}$ wymiarze niewłaściwym dotyczyłaby tych instrumentów, które nie wpisują się w katalog instrumentów reglamentacji przewidzianych w Prawie przedsiębiorców, choć bezsprzecznie warunkują dopuszczalność podjęcia działalności gospodarczej określonych rodzajów, wywołując tym samym skutek tożsamy jak instrumenty wynikające z Prawa przedsiębiorców.

W obrębie niewłaściwej reglamentacji podejmowania działalności gospodarczej zasadne wydaje się wyróżnienie trzech kategorii, odzwierciedlających różnorodność gałęzi prawa, z których przepisów mogą wynikać ograniczenia swobody podejmowania określonych rodzajów działalności gospodarczej. Najszerszą kategorię będzie stanowić prawnogospodarcza reglamentacja podejmowania działalności gospodarczej, w której wypadku ograniczenia będą stanowić element regulacji (publicznego) prawa gospodarczego. Obecność unormowań o podobnym skutku w przepisach prawa administracyjnego i prawa podatkowego daje podstawę do wyróżnienia także prawnoadministracyjnej i prawnopodatkowej reglamentacji podejmowania działalności gospodarczej.

\section{Prawnogospodarcza (niewłaściwa) reglamentacja podejmowania działalności gospodarczej}

W przepisach (publicznego) prawa gospodarczego można wyróżnić instrumenty niewłaściwej reglamentacji podejmowania działalności gospodarczej o charakterze zarówno indywidualnych aktów administracyjnych, jak i wpisów do rejestrów prowadzonych przez właściwe organy władzy publicznej — są to więc instrumenty, które można uznać za refleksy instrumentów reglamentacji

12 Zob. K. Kiczka, Z teorii i praktyki reglamentacji gospodarczej, [w:] Jednostka wobec wtadczej ingerencji organów administracji publicznej. Księga jubileuszowa dedykowana Profesor Barbarze Adamiak, red. J. Korczak, K. Sobieralski, Wrocław 2019, s. 232. 
właściwej, to jest koncesji i zezwoleń, a także wpisów do rejestrów działalności regulowanej.

Wśród instrumentów o charakterze aktów administracyjnych warto wspomnieć o decyzji w sprawie zatwierdzenia (projektu) zakładu, o której traktują przepisy ustawy z dnia 16 grudnia 2005 roku o produktach pochodzenia zwierzęcego $^{13}$ oraz ustawy z dnia 25 sierpnia 2006 roku o bezpieczeństwie żywności i żywienia ${ }^{14}$. Zgodnie z art. 19 ust. 1 i 2 pierwszego ze wskazanych aktów prawnych podjęcie działalności $\mathrm{w}$ zakresie produkcji produktów pochodzenia zwierzęcego wymaga uprzedniego uzyskania decyzji administracyjnej w przedmiocie zatwierdzenia projektu technologicznego zakładu produkcji, wydanej przez powiatowego lekarza weterynarii. Wymagania dotyczące projektu technologicznego zakładu, których spełnienie warunkuje wydanie pozytywnej decyzji, zostały określone w rozporządzeniu Ministra Rolnictwa i Rozwoju Wsi z dnia 18 marca 2013 roku w sprawie wymagań, jakie powinien spełniać projekt technologiczny zakładu, w którym ma być prowadzona działalność w zakresie produkcji produktów pochodzenia zwierzęcego ${ }^{15}$, wydanym na podstawie upoważnienia zawartego w art. 19 ust. 5 ustawy. Z kolei ustawa o bezpieczeństwie żywności i żywienia zawiera regulacje limitujące dopuszczalność podjęcia działalności w zakresie między innymi produkcji lub wprowadzania do obrotu żywności pochodzenia niezwierzęcego lub wprowadzania do obrotu produktów pochodzenia zwierzęcego, nieobjętych urzędową kontrolą organów Inspekcji Weterynaryjnej. Na podstawie art. 63 ustawy rozpoczęcie tego rodzaju działalności może nastąpić po zatwierdzeniu lub warunkowym zatwierdzeniu zakładu, co następuje w drodze decyzji wydanej przez państwowego powiatowego inspektora sanitarnego lub państwowego granicznego inspektora sanitarnego.

Stypizowane w Prawie przedsiębiorców indywidualne akty administracyjne będące wyrazem właściwej reglamentacji podejmowania działalności gospodarczej (koncesje i zezwolenia) oraz decyzje w sprawie zatwierdzenia (projektu) zakładu wykazują podobieństwa w perspektywie aposteriorycznej — wywołują po stronie przedsiębiorcy zainteresowanego rozpoczęciem działalności gospodarczej określonego rodzaju zbliżony skutek w postaci zaistnienia prawnej dopuszczalności podjęcia tej działalności. Są jednak odmienne w perspektywie apriorycznej, $\mathrm{w}$ związku z różniącą je naturą prawną. Koncesje i zezwolenia mają charakter aktów administracyjnych zezwalających, zwalniających przedsiębiorcę z ogólnego zakazu wykonywania danej działalności ${ }^{16}$. Decyzje w sprawie zatwierdzenia (projektu) zakładu należy natomiast uznać za akty kwalifikacyjne o charakterze

13 Dz.U. z 2019 r. poz. 824 ze zm.

14 Dz.U. z 2019 r. poz. 1252 ze zm.

15 Dz.U. z 2013 r. poz. 434.

16 Zgodnie z koncepcją zakazu z zastrzeżeniem pozwolenia autorstwa O. Mayera wydanie pozwolenia sprawia, że adresat pozwolenia zostaje wyłączony spod powszechnego zakazu podejmowania określonych czynności lub działalności; zob. idem, Deutsches Verwaltungsrecht, t. 1, 
przedmiotowym ${ }^{17}$ — ich istotą jest kwalifikacja (projektu) zakładu produkcji jako spełniającego wymagania mające zapewnić wysoki stopień bezpieczeństwa i higieny. Nie sposób zatem przyjąć, że we wskazanych dziedzinach działalności gospodarczej, normowanych ustawą o produktach pochodzenia zwierzęcego oraz ustawą o bezpieczeństwie żywności i żywienia, obowiązuje ogólny zakaz wykonywania działalności - ograniczenie swobody podejmowania działalności gospodarczej jest tu uzasadnione wyłącznie dążeniem do odsunięcia zagrożenia dla dóbr policyjnych wskutek wykonywania działalności w warunkach bazy materialnej tym dobrom zagrażających.

Refleksem stypizowanego w Prawie przedsiębiorców wpisu do rejestru działalności regulowanej są w sferze reglamentacji niewłaściwej wpisy do innych rejestrów działalności gospodarczej - działalności, którym ustawodawca nie zdecydował się nadać charakteru działalności regulowanej ${ }^{18}$. Uzyskania wpisu do szczególnego rejestru wymaga podjęcie działalności gospodarczej w zakresie między innymi obrotu leśnym materiałem rozmnożeniowym (art. 45 ustawy z dnia 7 czerwca 2001 roku o leśnym materiale rozmnożeniowym ${ }^{19}$ ), organizowania wyścigów konnych (art. 16 ustawy z dnia 18 stycznia 2001 roku o wyścigach konnych ${ }^{20}$ ), a także hodowli, dostarczania zwierząt lub wykonywania procedur (art. 26 ustawy z dnia 15 stycznia 2015 roku o ochronie zwierząt wykorzystywanych do celów naukowych lub edukacyjnych ${ }^{21}$ ). Podobnie jak w wypadku reglamentacji niewłaściwej w zakresie indywidualnych aktów administracyjnych także w odniesieniu do rejestrów działalności gospodarczej reglamentacja niewłaściwa koncentruje się wokół dziedzin działalności, w których następuje wykorzystanie dóbr przyrody ożywionej i nieożywionej. Takie dziedziny działalności ze swej istoty są bowiem związane ze szczególnym niebezpieczeństwem naruszenia stanów i dóbr policyjnych (przede wszystkim życia, zdrowia i środowiska naturalnego), podlegających w systemie prawa najszerszej ochronie.

München-Leipzig 1924, s. 243. O krytyce koncepcji zakazu z zastrzeżeniem pozwolenia zob. D.R. Kijowski, Pozwolenia w administracji publicznej, Białystok 2000, s. 48-49.

17 K. Kiczka, Inne akty administracyjne w publicznym prawie gospodarczym, [w:] System Prawa Administracyjnego, t. 8b. Publiczne prawo gospodarcze, red. J. Grabowski, L. Kieres, A. Walaszek-Pyziol, Warszawa 2018, s. 540-541.

$18 \mathrm{~W}$ art. 45 ust. 1 ustawy z dnia 5 lipca 2018 roku o zarządzie sukcesyjnym przedsiębiorstwem osoby fizycznej (Dz.U. poz. 1629 ze zm.) ustawodawca daje wyraz świadomości istnienia dziedzin działalności gospodarczej zbliżonych do działalności regulowanej poprzez wymóg uzyskania wpisu do pewnego szczególnego rejestru działalności gospodarczej — zgodnie z regulacją zawartą $\mathrm{w}$ powołanym przepisie unormowania $\mathrm{z}$ art. 45 ust. 2-8 ustawy znajdują zastosowanie do „działalności regulowanej oraz działalności wymagającej wpisu do innego niż rejestr działalności regulowanej rejestru prowadzonego przez organ administracji publicznej”.

19 Dz.U. z 2019 r. poz. 1097.

20 Dz.U. z 2017 r. poz. 194 ze zm.

21 Dz.U. z 2019 r. poz. 1392 ze zm. 
Wydaje się, że decyzja ustawodawcy o usytuowaniu wskazanych rodzajów działalności gospodarczej poza reżimem prawnym działalności regulowanej była uzasadniona dążeniem do wyłączenia ich z zakresu obowiązywania korzystnych dla przedsiębiorców unormowań dotyczących wpisu do rejestru działalności regulowanej, których zastosowanie mogło wydawać się niepożądane w dziedzinach działalności o znacznej doniosłości dla dóbr policyjnych. Przede wszystkim należy przytoczyć tu regułę wynikającą z art. 67 ust. 2 nieobowiązującej już ustawy z dnia 2 lipca 2004 roku o swobodzie działalności gospodarczej ${ }^{22}$, zgodnie z którą jeżeli organ prowadzący rejestr działalności regulowanej nie dokonał wpisu w terminie 7 dni od dnia wpływu wniosku o wpis, a od dnia wpływu wniosku do tego organu upłynęło 14 dni, przedsiębiorca mógł rozpocząć działalność bez uzyskania wpisu - obecnie przytoczone unormowanie jest zawarte w wielu ustawach szczegółowych regulujących dane dziedziny działalności regulowanej ${ }^{23}$. Dopuszczenie możliwości podjęcia działalności relewantnej dla życia, zdrowia i środowiska naturalnego bez formalnej choćby autoryzacji ze strony organów władzy publicznej (w postaci dokonania wpisu do rejestru ${ }^{24}$ ) mogło zostać zatem uznane za przejaw niezasługującej na aprobatę ustawodawcy dominacji interesów przedsiębiorców nad szczególnie doniosłym interesem publicznym.

\section{Prawnoadministracyjna (niewłaściwa) reglamentacja podejmowania działalności gospodarczej}

Wyznaczenie granicy między regulacjami ograniczającymi swobodę podejmowania określonych rodzajów działalności gospodarczej stanowiącymi część (publicznego) prawa gospodarczego i prawa administracyjnego nie jest zagadnieniem w pełni precyzyjnym $\mathrm{i}$ jednoznacznym. W niniejszym artykule przyjęto rozróżnienie, zgodnie z którym w obrębie reglamentacji prawnogospodarczej będą sytuowane instrumenty ograniczające swobodę podejmowania działalności gospodarczej stanowiące część szerszej regulacji swoiście odnoszącej się do działalności gospodarczej jako wyodrębnionej dziedziny działalności ludz-

22 Dz.U. z 2017 r. poz. 2168 ze zm.

23 Zob. np. art. 51 ca ust. 2 ustawy z dnia 14 lipca 1983 roku o narodowym zasobie archiwalnym i archiwach (Dz.U. z 2019 r. poz. 553 ze zm.) oraz art. 30a ust. 2 ustawy z dnia 4 lutego 2011 roku o opiece nad dziećmi w wieku do lat 3 (Dz.U. z 2019 r. poz. 409 ze zm.).

24 O charakterze wpisu do rejestru działalności regulowanej zob. K. Horubski, Komentarz do art. 43 Prawa przedsiębiorców, [w:] Konstytucja biznesu. Komentarz, red. M. Wierzbowski, Warszawa 2019, s. 184-185. 
$\mathrm{kiej}^{25}$. Ograniczenie swobody podejmowania działalności gospodarczej ma tu charakter pierwotny - jest celowo zastosowanym przez ustawodawcę zabiegiem nastawionym na ochronę pewnych dóbr i interesów w sferze gospodarki, sformułowanym wprost w tekście aktu prawnego. Do reglamentacji prawnoadministracyjnej będą natomiast należały unormowania odnoszące się do różnych dziedzin działalności człowieka, wywierające wpływ między innymi na podejmowanie i wykonywanie działalności gospodarczej — ograniczenie swobody podejmowania działalności gospodarczej jest w tym wypadku tylko wtórnym skutkiem regulacji oddziałującej na wiele sfer aktywności społecznej.

Istotną płaszczyzną, w której materializują się instrumenty prawnoadministracyjnej (niewłaściwej) reglamentacji podejmowania działalności gospodarczej, są przepisy prawa ochrony środowiska. Wymogiem warunkującym dopuszczalność podjęcia działalności gospodarczej w dziedzinach o wysokim stopniu interakcji ze środowiskiem naturalnym jest przeprowadzenie oceny oddziaływania przedsięwzięcia na środowisko. Zgodnie z art. 59 ust. 1 ustawy z dnia 3 października 2008 roku o udostępnianiu informacji o środowisku i jego ochronie, udziale społeczeństwa $\mathrm{w}$ ochronie środowiska oraz o ocenach oddziaływania na środowisko ${ }^{26}$ przeprowadzenia oceny wymaga realizacja planowanego przedsięwzięcia mogącego zawsze znacząco oddziaływać na środowisko, realizacja zaś planowanego przedsięwzięcia mogącego potencjalnie znacząco oddziaływać na środowisko wiąże się z koniecznością przeprowadzenia oceny, jeżeli wynika to z postanowienia wydanego przez organ właściwy do wydania decyzji o środowiskowych uwarunkowaniach na podstawie art. 63 ust. 1 ustawy.

Rodzaje przedsięwzięć mogących zawsze znacząco oddziaływać na środowisko oraz przedsięwzięć mogących potencjalnie znacząco oddziaływać na środowisko zostały określone w rozporządzeniu Rady Ministrów z dnia 10 września 2019 roku w sprawie przedsięwzięć mogących znacząco oddziaływać na środowisko ${ }^{27}$, wydanym na podstawie art. 60 omawianej ustawy. Na podstawie przepisów rozporządzenia można zatem stwierdzić, że przeprowadzenie oceny oddziaływania na środowisko warunkuje dopuszczalność podjęcia działalności gospodarczej między innymi w zakresie pierwotnego i wtórnego wytopu surówki żelaza lub stali surowej, prażenia lub spiekania rud metali, a także prowadzenia rafinerii ropy naftowej, które zostały uznane za przedsięwzięcia mogące zawsze znacząco oddziaływać na środowisko ( $\$ 2$ ust. 1 pkt 9, 10 i 23 rozporządzenia). Do przedsięwzięć mogących potencjalnie znacząco oddziaływać na środowisko należy natomiast wykonywanie działalności gospodarczej między innymi w za-

25 O pojmowaniu działalności gospodarczej jako przedmiotu regulacji prawa gospodarczego, to jest kategorii relewantnej dla wyznaczenia granic prawa gospodarczego, zob. W. Małecki, Policja gospodarcza w prawie gospodarczym. Ujęcie teoretyczne, Warszawa 2019, s. 130-160.

26 Dz.U. z 2018 r. poz. 2081 ze zm.

27 Dz.U. z 2019 r. poz. 1839. 
kresie prowadzenia stoczni produkcyjnych lub remontowych, a także prowadzenia parków rozrywki ( 33 ust. 1 pkt 48 i 59 rozporządzenia).

O prawnoadministracyjnym (a nie prawnogospodarczym) charakterze opisanych unormowań reglamentacyjnych świadczy odniesienie ich także do innych niż działalność gospodarcza dziedzin działalności ludzkiej. Zgodnie z $§ 2$ ust. 1 pkt 35, § 3 ust. 1 pkt 55, 57, 67 i 90 rozporządzenia przedsięwzięciami mogącymi zawsze lub potencjalnie znacząco oddziaływać na środowisko, które wymagają przeprowadzenia oceny oddziaływania na środowisko, są między innymi zapory lub inne urządzenia przeznaczone do zatrzymywania i stałego retencjonowania masy wody, budowle przeciwpowodziowe, zalesienia, zabudowa mieszkaniowa wraz z towarzyszącą jej infrastrukturą, a także szpitale i placówki edukacyjne.

\section{Prawnopodatkowa (niewłaściwa) reglamentacja podejmowania działalności gospodarczej}

Prawnopodatkowa reglamentacja podejmowania działalności gospodarczej poddaje się łatwemu odróżnieniu od reglamentacji prawnogospodarczej i prawnoadministracyjnej, co wynika choćby z wyraźnej odrębności źródeł prawa podatkowego w systemie prawa. Niewątpliwie zatem ograniczenia swobody podejmowania określonych rodzajów działalności gospodarczej wywodzone z przepisów ustaw podatkowych należy rozpatrywać odrębnie od ograniczeń o genezie prawnogospodarczej i prawnoadministracyjnej, o czym przesądza szeroka autonomia prawa podatkowego, wyrażająca się między innymi w swoistych zasadach jego wykładni ${ }^{28}$.

Ważnym instrumentem warunkującym dopuszczalność podjęcia działalności gospodarczej w pewnych dziedzinach jest zezwolenie na prowadzenie składu podatkowego, o którym mowa w art. 48 ustawy z dnia 6 grudnia 2008 roku o podatku akcyzowym ${ }^{29}$. O jego doniosłości w obszarze reglamentacji podejmowania działalności gospodarczej stanowi art. 47 ust. 1 ustawy, zgodnie z którym ,produkcja wyrobów akcyzowych określonych w załączniku nr 2 do ustawy, w tym opodatkowanych zerową stawką akcyzy ze względu na ich przeznaczenie, oraz wyrobów akcyzowych innych niż określone w załączniku nr 2 do ustawy, objętych stawką akcyzy inną niż stawka zerowa, może odbywać się wyłącznie w składzie podatkowym”. Uzyskanie zezwolenia, wydawanego przez właściwego naczelni-

28 O autonomii prawa podatkowego zob. m.in. W. Nykiel, Autonomia prawa podatkowego (wybrane zagadnienia), [w:] Konstytucja, ustrój, system finansowy państwa. Księga pamiątkowa ku czci prof. Natalii Gajl, red. T. Dębowska-Romanowska, A. Jankiewicz, Warszawa 1999, s. 397 n.; M. Koszowski, Autonomia prawa podatkowego — argumenty za i przeciw, „Przegląd Prawa Publicznego” 2013, nr 11, s. $42 \mathrm{n}$.

29 Dz.U. z 2019 r. poz. 864 ze zm. 
ka urzędu skarbowego, warunkuje zatem dopuszczalność podjęcia działalności gospodarczej w zakresie produkcji wyrobów akcyzowych. Załącznik numer 2 do ustawy wśród wyrobów akcyzowych, których produkcja odbywa się w składzie podatkowym, wymienia między innymi oleje i ich frakcje (olej sojowy, z orzeszków ziemnych, palmowy, z nasion słonecznika, kokosowy, z ziaren palmowych, rzepakowy), margarynę oraz piwo otrzymywane ze słodu.

Przesłanki decydujące o ograniczeniu swobody podejmowania działalności gospodarczej wymogiem uzyskania zezwolenia na prowadzenie składu podatkowego są diametralnie różne od przesłanek uzasadniających ograniczenia prawnogospodarcze i prawnoadministracyjne. Nie wchodzi tu bowiem w grę ochrona stanów i dóbr policyjnych lub innych wartości doniosłych dla interesu publicznego. $\mathrm{O}$ istocie produkcji prowadzonej $\mathrm{w}$ składzie podatkowym stanowi zastosowanie procedury zawieszenia poboru akcyzy — zgodnie z art. 2 ust. 1 pkt 12 ustawy o podatku akcyzowym procedura ta dotyczy sytuacji, gdy z obowiązku podatkowego nie powstaje zobowiązanie podatkowe - dopóki wyrób akcyzowy znajduje się w składzie podatkowym (lub jest przemieszczany w sposób wskazany w ustawie), na podmiocie prowadzącym skład podatkowy nie ciąży zobowiązanie podatkowe w zakresie podatku akcyzowego. Prowadzenie produkcji wyrobów akcyzowych w składzie podatkowym jest więc związane $\mathrm{z}$ odsunięciem w czasie zapłaty podatku ${ }^{30}$.

\section{Podsumowanie}

Przedstawione w niniejszym artykule instrumenty prawne warunkujące dopuszczalność podjęcia określonych rodzajów działalności gospodarczej, znajdujące się poza katalogiem instrumentów stypizowanych w przepisach Prawa przedsiębiorców, wykazują daleko posunięte odmienności związane z ich formą i naturą prawną, przesłankami uzasadniającymi wprowadzenie ich do systemu prawa oraz przynależnością do gałęzi prawa. O zasadności usytuowania ich w ramach kategorii niewłaściwej reglamentacji podejmowania działalności decyduje tożsamy skutek wywierany wobec podmiotów zainteresowanych podjęciem danej działalności - dopiero z chwilą uzyskania stosownej ,,autoryzacji” ze strony właściwego organu władzy publicznej (w postaci indywidualnego aktu administracyjnego lub wpisu do rejestru) podmiot nabywa uprawnienie do podjęcia danej działalności gospodarczej.

Rozproszenie instrumentów niewłaściwej reglamentacji podejmowania działalności gospodarczej w trzech różnych gałęziach prawa jest także odzwiercie-

30 Wyrok Naczelnego Sądu Administracyjnego z dnia 9 września 2016 roku, sygn. I GSK $701 / 15$ 
dleniem dualizmu prawnej regulacji działalności gospodarczej - działalność gospodarcza jest bowiem poddana regulacji ogólnej i swoistej. Regulacja swoista materializuje się w sferze prawa gospodarczego, którego normy w swych zakresach zastosowania ujmują jedynie stany faktyczne związane $\mathrm{z}$ wykonywaniem działalności gospodarczej. Są to więc unormowania dotyczące wyłącznie działalności gospodarczej jako swoiście wyodrębnionej dziedziny działalności człowieka. Regulacja ogólna, sytuowana poza prawem gospodarczym (w szczególności w prawie administracyjnym), odnosi się zaś do różnych dziedzin działalności, do których należy między innymi działalność gospodarcza. Nie jest zatem tak, że wszystkie normy znajdujące zastosowanie wobec podejmowania i wykonywania działalności gospodarczej należą do prawa gospodarczego.

\section{Bibliografia}

Dębiński A., Rzymskie prawo prywatne, Warszawa 2008.

Horubski K., Komentarz do art. 43 Prawa przedsiębiorców, [w:] Konstytucja biznesu. Komentarz, red. M. Wierzbowski, Warszawa 2019.

Kiczka K., Inne akty administracyjne w publicznym prawie gospodarczym, [w:] System Prawa Administracyjnego, t. 8b. Publiczne prawo gospodarcze, red. J. Grabowski, L. Kieres, A. Walaszek-Pyzioł, Warszawa 2018.

Kiczka K., Z teorii i praktyki reglamentacji gospodarczej, [w:] Jednostka wobec władczej ingerencji organów administracji publicznej. Księga jubileuszowa dedykowana Profesor Barbarze Adamiak, red. J. Korczak, K. Sobieralski, Wrocław 2019.

Kiczka K., Kocowski T., Małecki W., Licencje jako akty administracyjne w działalności gospodarczej. Zagadnienia wybrane, [w:] Sektory infrastrukturalne. Problematyka prawna, red. M. Królikowska-Olczak, Warszawa 2018.

Kijowski D.R., Pozwolenia w administracji publicznej, Białystok 2000.

Kocowski T., Reglamentacja działalności gospodarczej, [w:] System Prawa Administracyjnego, t. 8a. Publiczne prawo gospodarcze, red. J. Grabowski, L. Kieres, A. Walaszek-Pyzioł, Warszawa 2018.

Kocowski T., Reglamentacja działalności gospodarczej w polskim administracyjnym prawie gospodarczym, Wrocław 2009.

Koszowski M., Autonomia prawa podatkowego - argumenty za i przeciw, „Przegląd Prawa Publicznego" 2013, nr 11.

Małecki W., Policja gospodarcza w prawie gospodarczym. Ujęcie teoretyczne, Warszawa 2019.

Mayer O., Deutsches Verwaltungsrecht, t. 1, München-Leipzig 1924.

Nykiel W., Autonomia prawa podatkowego (wybrane zagadnienia), [w:] Konstytucja, ustrój, system finansowy państwa. Księga pamiątkowa ku czci prof. Natalii Gajl, red. T. Dębowska-Romanowska, A. Jankiewicz, Warszawa 1999.

Popowska B., Klasyfikacja funkcji administracji w nauce publicznego prawa gospodarczego, [w:] Funkcje wspótczesnej administracji gospodarczej, red. B. Popowska, Poznań 2006.

Strzelbicki M., Reglamentacja działalności gospodarczej w świetle ustawy Prawo przedsiębiorców na tle unormowań wcześniejszych, „Ruch Prawniczy, Ekonomiczny i Socjologiczny” 2018, nr 4.

Strzyczkowski K., Prawo gospodarcze publiczne, Warszawa 2011. 
Szydło M., Reglamentacja podejmowania działalności gospodarczej w nowej ustawie o swobodzie działalności gospodarczej, „Przegląd Ustawodawstwa Gospodarczego” 2004, nr 12.

Szydło M., Swoboda działalności gospodarczej, Wrocław 2005.

Waligórski M., Administracyjna regulacja działalności gospodarczej. Problemy prawnej reglamentacji, Poznań 1998.

\title{
Reglamentation of undertaking of economic activity - proper and improper dimensions
}

\begin{abstract}
Summary
The catalog of instruments of reglamentation of economic activity included in chapter 4 of the Law of Entrepreneurs (concession, permit, entry in the register of regulated economic activity) does not exhaust the general structure of the reglamentation of undertaking economic activity in the Polish legal system. Numerous laws regarding specific fields of economic activity regulate legal instruments determining the admissibility of undertaking economic activity, which are located outside the catalog resulting from the provisions of the Law of Entrepreneurs. Although they have a similar effect to instruments arising from the Law of Entrepreneurs, their legal substance is different. These instruments should be included in the category of improper reglamentation of undertaking economic activity, in contrast to the proper reglamentation, which falls within the structure included in chapter 4 of the Law of Entrepreneurs. The instruments of improper reglamentation of undertaking economic activity are dispersed in three different branches of law - economic law, administrative law, and tax law.
\end{abstract}

Keywords: reglamentation of economic activity, improper reglamentation, concession, permit, regulated economic activity. 